\title{
Uptake of Screening for Diabetic Retinopathy and Associated Factors among Adults with Diabetes Mellitus Aged 18-65 Years: A Descriptive Cross Sectional Study
}

\author{
Doreen M. Mukona, Precious Dzingira, M. Mhlanga, M. Zvinavashe
}

\begin{abstract}
The prevalence of diabetes in Zimbabwe has increased significantly in the past three decades posing serious challenges to the provision of care and prevention of disabling co-morbidities in an already disadvantaged healthcare setting. Studies conducted in Zimbabwe have reported prevalence of $16 \%$ to $38 \%$. Diabetic retinopathy, a major complication of diabetes, is a leading cause of blindness globally and of an estimated 285 million people with diabetes worldwide approximately $33.3 \%$ have signs of diabetic retinopathy and of these a further $33.3 \%$ have vision threatening diabetic retinopathy. The purpose of this study is to examine uptake of screening for diabetic retinopathy and associated factors among adults aged 18-65 years with diabetes at Parirenyatwa Group of Hospitals. This was a cross sectional analytical study on a random sample of 83 adults aged 18-65 years with diabetes mellitus. The study was conducted according to the requirements of the Declaration of Helsinki. A structured questionnaire was used to collect data in strict privacy and confidentiality. Uptake of screening was $53 \%$. The chi-square test was done to analyze demographic factors associated with uptake of screening. Male gender and being married were significantly associated with higher uptake of screening ( $p=0.029$ and $p=0.037$ respectively). Logistic regression was done to determine predictors of uptake of screening services for diabetic retinopathy. On logistic regression, gender $(O R=0.241$, 95\% CI $[0.079-0.735])$ and misinformation $(\mathrm{OR}=0.280,95 \%$ CI [0.081 - 0.974]) were significant predictors of uptake of screening. Uptake of diabetic retinopathy screening was suboptimal. Gender and misinformation were significant barriers to uptake of screening. There is need to address barriers to uptake of retinopathy screening to promote timely identification and management of complications in people with diabetes mellitus.
\end{abstract}

Key words - diabetes mellitus; retinopathy; screening; uptake.

\section{INTRODUCTION}

The prevalence of diabetes in Zimbabwe has increased significantly in the past three decades posing serious challenges to the provision of care and prevention of disabling co-morbidities in an already disadvantaged healthcare setting [1]. Studies conducted in Zimbabwe have reported prevalence of $16 \%$ to $38 \%$ [2]-[4]. Diabetes is associated with complications such as heart attacks, strokes, neuropathy, nephropathy and retinopathy. Diabetic

Published on July 22, 2020.

D. M. Mukona, University of Zimbabwe College of Health Sciences, Zimbabwe.

(corresponding e-mail: dmacherera ${ }^{@}$ yahoo.co.uk)

P. Dzingira, University of Zimbabwe College of Health Sciences, Zimbabwe.

(e-mail: preciousdzingiramapfuurire@ gmail.com) retinopathy is a leading cause of blindness globally and of an estimated 285 million people with diabetes worldwide approximately $33.3 \%$ have signs of diabetic retinopathy and of these a further $33.3 \%$ have vision threatening diabetic retinopathy[5]. According to WHO, diabetic retinopathy is an important cause of blindness which results from long term accumulated damage to the small blood vessels in the retina and $2.6 \%$ of global blindness is attributed to diabetes. It is the fifth commonest cause of blindness and is responsible for a disproportionately larger quantum of associated morbidity [3]. The primary method of screening for diabetic retinopathy is ophthalmoscopy, done with or without pharmacologic dilation [6]. The American Diabetes Association (ADA) 2014 guidelines state that type 1 diabetics should have a comprehensive eye examination done within 5 years after the onset of diabetes while type 2 diabetics require an eye examination at the time of diagnosis and once a year there after. Pregnant women with diabetes need to have their eyes examined in the first trimester of pregnancy, with close monitoring throughout pregnancy and 1 year post-partum as pregnancy can quickly exacerbate underlying diabetic retinopathy [6].

Despite the high prevalence of diabetic retinopathy, research studies have identified reduced uptake of the recommended annual eye screening. Annual diabetic retinopathy screening is recommended by the International Council of Ophthalmology and the World Health Organisation [4]. Adherence to retinopathy screening is sub optimal and multifactorial in nature [6]. The diabetic eye screening program defines $75 \%$ as the minimum acceptable level of uptake for the current Quality Assurance Standard with $85 \%$ considered achievable [7]. Screening attendance rates for diabetic retinopathy consistently below recommended levels have been observed internationally [8].

The reduced uptake of diabetic retinopathy eye screening is attributed to various barriers and enablers. Population eye screening among people with diabetes has been shown to be clinically effective but it is associated with suboptimal attendances with a wide range of demographic disparities [8]. Some reported reasons for low uptake of screening include long waiting periods, and limited health facilities offering the service [4]. The purpose of this study, therefore, was to assess uptake of screening for diabetic retinopathy and associated

M. Mhlanga, University of Zimbabwe College of Health Sciences, Zimbabwe.

(e-mail: profmaxmhlanga7a@gmail.com)

M. Zvinavashe, University of Zimbabwe College of Health Sciences, Zimbabwe.

(e-mail: zvinavam ${ }^{\circledR}$ gmail.com) 
factors among adults aged 18-65 years with diabetes at Parirenyatwa Group of Hospitals.

\section{METHODOLOGY}

This was a cross sectional study conducted on a random sample of 83 participants aged 18-69 years. The study was conducted at Parirenyatwa Group of Hospitals in the Out Patients' Department (OPD). Approval for the study was granted by the Joint Research and Ethics Committee of the University of Zimbabwe College of Health Sciences and Parirenyatwa Group of Hospitals. All participants gave informed consent. An interviewer administered questionnaire was used to collect data. It had sections on demographic data, uptake of diabetic retinopathy screening and reasons for nonuptake of screening. All interviews were held in a private room and code numbers were used to identify participants and filled in questionnaires were kept in a lockable cupboard to which the researcher had sole access. Data was analysed using SPSS version 22 and STATA version. Descriptive statistics were used to analyse demographic data, screening rates and barriers to uptake of screening. The chi-square test was done to analyse demographic factors associated with uptake of screening. Logistic regression was done to determine predictors of uptake of screening services for diabetic retinopathy.

\section{RESULTS}

Table 1 presents socio demographic data. A greater proportion of participants who were not screened for diabetic retinopathy were females 16(59.3\%) and gender was significantly associated with uptake of screening $(\mathrm{p}=0.029)$. The majority of the participants were married $55(66.3 \%)$ and being married was associated with higher uptake of screening $(\mathrm{p}=0.037)$. About $51 \%$ of the participants were unemployed and the greater proportion of the participants were Christians $52(62.7 \%)$. Education level had no significant association with screening rates with only $17(20.5 \%)$ of the participants having no formal education. The majority of the participants $55(66.3 \%)$ lived in urban high density and type 2 diabetes was the most prevalent in both groups. A greater proportion of participants had lived with the diagnosis of diabetic retinopathy for $0-2$ years $37(44.6 \%)$ and there was a relatively fair distribution of participants by age in both screened and unscreened participants.

Barriers to uptake of diabetic retinopathy screening

Table 2 presents barriers to uptake of screening. Majority participants who had not been screened cited competing priorities $17(63.0 \%)$ and long waiting periods $16(59.3 \%)$, as barriers. Misinformation, lack of motivation, attitudes and knowledge levels were significant barriers to uptake ( $\mathrm{p}=0.024, \mathrm{p}=0.048, \mathrm{p}=0.011$ and $\mathrm{p}=0.035$ respectively).

TABLE 1: SOCIO-DEMOGRAPHIC CHARACTERISTICS (N=83)

\begin{tabular}{|c|c|c|c|c|}
\hline \multirow{2}{*}{$\begin{array}{c}\text { Variable } \\
(n=83)\end{array}$} & \multicolumn{2}{|c|}{ Screening status } & \multirow{2}{*}{ Totals (\%) } & \multirow{2}{*}{$\begin{array}{c}\text { Chi- } \\
\text { square } \\
\text { p-value }\end{array}$} \\
\hline & No $(\%)$ & Yes $(\%)$ & & \\
\hline $\begin{array}{l}\text { Gender } \\
\text { Male } \\
\text { Female } \\
\text { Total } \\
\end{array}$ & $\begin{array}{c}11(40.7) \\
16(59.3) \\
27(100.0)\end{array}$ & $\begin{array}{c}37(66.1) \\
19(33.9) \\
56(100.0) \\
\end{array}$ & $\begin{array}{c}48(57.8) \\
35(42.2) \\
83(100.0) \\
\end{array}$ & $0.029 *$ \\
\hline $\begin{array}{l}\text { Marital status } \\
\text { Single } \\
\text { Married } \\
\text { Widowed } \\
\text { Total } \\
\end{array}$ & $\begin{array}{c}6(22.2) \\
15(55.6) \\
6(22.2) \\
27(100.0) \\
\end{array}$ & $\begin{array}{c}9(16.1) \\
40(71.4) \\
7(12.5) \\
56(100.0) \\
\end{array}$ & $\begin{array}{c}15(18.1) \\
55(66.3) \\
13(15.7) \\
83\end{array}$ & $0.037 *$ \\
\hline $\begin{array}{l}\text { Employment } \\
\text { Formal } \\
\text { Unemployed } \\
\text { Informal } \\
\text { Total } \\
\end{array}$ & $\begin{array}{c}14(51.9) \\
11(40.7) \\
2(7.4) \\
27(100.0) \\
\end{array}$ & $\begin{array}{c}22(39.3) \\
31(55.4) \\
3(5.4) \\
56(100.0) \\
\end{array}$ & $\begin{array}{c}36(43.4) \\
42(50.6) \\
5(6.0) \\
83(100.0)\end{array}$ & 0.481 \\
\hline $\begin{array}{l}\text { Religion } \\
\text { Christian } \\
\text { Islam } \\
\text { Traditional } \\
\text { Non-believer } \\
\text { Other } \\
\text { Total } \\
\end{array}$ & $\begin{array}{c}17(63.0) \\
5(18.5) \\
3(11.1) \\
1(3.7) \\
1(3.7) \\
27(100.0) \\
\end{array}$ & $\begin{array}{c}35(62.5) \\
12(21.4) \\
2(3.6) \\
7(12.5) \\
0(0.0) \\
56(100.0) \\
\end{array}$ & $\begin{array}{c}52(62.7) \\
17(20.5) \\
5(6.0) \\
8(9.6) \\
1(1.2) \\
83(100.0) \\
\end{array}$ & 0.255 \\
\hline $\begin{array}{l}\text { Education } \\
\text { ZJC } \\
\text { Ordinary level } \\
\text { Advanced } \\
\text { level } \\
\text { Tertiary } \\
\text { Never went to } \\
\text { school } \\
\text { Total } \\
\end{array}$ & $\begin{array}{l}5(18.5) \\
7(25.9) \\
7(25.9) \\
5(18.5) \\
3(11.1) \\
27(100.0) \\
\end{array}$ & $\begin{array}{c}11(19.6) \\
17(30.3) \\
18(32.1) \\
4(7.1) \\
6(10.7) \\
56(100.0) \\
\end{array}$ & $\begin{array}{l}16(19.3) \\
24(28.9) \\
25(30.1) \\
9(10.8) \\
9(10.8) \\
83(100.0) \\
\end{array}$ & 0.636 \\
\hline $\begin{array}{l}\text { Income } \\
\text { (RTGS) } \\
<500 \\
500-1000 \\
>1000 \\
\text { Total } \\
\end{array}$ & $\begin{array}{c}14(51.9) \\
9(33.3) \\
4(14.8) \\
27(100.0)\end{array}$ & $\begin{array}{c}28(50.0) \\
15(26.8) \\
13(23.2) \\
56(100.0)\end{array}$ & $\begin{array}{c}42(50.6) \\
24(28.9) \\
17(20.5) \\
83(100.0)\end{array}$ & 0.291 \\
\hline $\begin{array}{l}\text { Residence } \\
\text { Urban high } \\
\text { density } \\
\text { Urban low } \\
\text { density } \\
\text { Total } \\
\end{array}$ & $\begin{array}{c}18(66.7) \\
9(33.3) \\
27(100.0) \\
\end{array}$ & $\begin{array}{l}37(66.1) \\
19(33.9) \\
56(100.0) \\
\end{array}$ & $\begin{array}{l}55(66.3) \\
28(33.7) \\
83(100.0) \\
\end{array}$ & 0.957 \\
\hline $\begin{array}{l}\text { Diabetes type } \\
\text { Type } 1 \\
\text { Type } 2 \\
\text { Total }\end{array}$ & $\begin{array}{c}2(3.8) \\
25(96.2) \\
27(100.0) \\
\end{array}$ & $\begin{array}{c}3(5.4) \\
53(94.6) \\
56(100.0) \\
\end{array}$ & $\begin{array}{c}5(6.0) \\
78(94.0) \\
83(100.0) \\
\end{array}$ & 0.114 \\
\hline $\begin{array}{l}\text { Duration with } \\
\text { diagnosis } \\
0-2 \text { years } \\
2-4 \\
4-6 \\
6-8 \\
8-10 \\
10-12 \\
12-14 \\
\text { Total } \\
\end{array}$ & $\begin{array}{c}10(37.0) \\
5(18.5) \\
7(25.9) \\
1(3.7) \\
2(7.4) \\
1(3.7) \\
1(3.7) \\
27(100.0)\end{array}$ & $\begin{array}{c}27(48.2) \\
9(16.1) \\
11(19.6) \\
5(8.9) \\
3(5.4) \\
0(0.0) \\
1(1.9) \\
56(100.0)\end{array}$ & $\begin{array}{c}37(44.6) \\
14(16.9) \\
18(21.7) \\
6(7.2) \\
5(6.0) \\
1(1.2) \\
2(2.4) \\
83(100.0)\end{array}$ & 0.667 \\
\hline $\begin{array}{l}\text { Age(yrs) } \\
18-25 \\
25-35 \\
35-45 \\
45-55 \\
55-65 \\
\text { Total } \\
\end{array}$ & $\begin{array}{c}6(22.2) \\
8(29.7) \\
8(29.7) \\
3(11.1) \\
2(7.4) \\
27(100.0) \\
\end{array}$ & $\begin{array}{c}7(12.5) \\
16(28.6) \\
14(25.0) \\
8(14.3) \\
11(19.6) \\
56(100.0) \\
\end{array}$ & $\begin{array}{c}13(15.7) \\
24(28.9) \\
22(26.5) \\
11(13.3) \\
13(15.7) \\
83(100.0) \\
\end{array}$ & 0.536 \\
\hline
\end{tabular}


TABLE 2: BARRIERS TO UPTAKE OF DIABETIC RETINOPATHY SCREENING $(\mathrm{N}=83)$

\begin{tabular}{|c|c|c|c|c|}
\hline \multirow[b]{2}{*}{ Variable } & \multicolumn{2}{|c|}{ Screening status } & \multirow[b]{2}{*}{ Total } & \multirow{2}{*}{$\begin{array}{c}\text { Chi- } \\
\text { square } \\
\text { p-value }\end{array}$} \\
\hline & $\begin{array}{c}\text { Not } \\
\text { screened }\end{array}$ & screened & & \\
\hline $\begin{array}{l}\text { Fear of laser } \\
\text { No } \\
\text { Yes } \\
\text { Total } \\
\end{array}$ & $\begin{array}{c}22(81.5) \\
5(19.5) \\
27(100.0) \\
\end{array}$ & $\begin{array}{c}52(92.9) \\
4(7.1) \\
56(100.0) \\
\end{array}$ & $\begin{array}{c}74(89.2) \\
9(10.8) \\
83(100.0) \\
\end{array}$ & 0.118 \\
\hline $\begin{array}{l}\text { Guilty of } \\
\text { glycaemic control } \\
\text { No } \\
\text { Yes } \\
\text { Total } \\
\end{array}$ & $\begin{array}{c}18(66.7) \\
9(33.3) \\
27(100.0) \\
\end{array}$ & $\begin{array}{c}41(73.2) \\
15(26.8) \\
56(100.0) \\
\end{array}$ & $\begin{array}{c}59(71.1) \\
24(28.9) \\
83(100.0) \\
\end{array}$ & 0.538 \\
\hline $\begin{array}{l}\text { Waiting } \\
\text { No } \\
\text { Yes } \\
\text { Total } \\
\end{array}$ & $\begin{array}{c}11(40.7) \\
16(59.3) \\
27(100.0) \\
\end{array}$ & $\begin{array}{c}25(44.6) \\
31(55.4) \\
56(100.0) \\
\end{array}$ & $\begin{array}{c}36(43.4) \\
47(56.6) \\
83(100.0) \\
\end{array}$ & 0.737 \\
\hline $\begin{array}{l}\text { Language } \\
\text { No } \\
\text { Yes } \\
\text { Total }\end{array}$ & $\begin{array}{c}27(100.0) \\
0(0.0) \\
27(100.0)\end{array}$ & $\begin{array}{c}56(100.0) \\
0(0.0) \\
56(100.0)\end{array}$ & $\begin{array}{c}83(100.0) \\
0(0.0) \\
83(100.0)\end{array}$ & \\
\hline $\begin{array}{l}\text { Pain } \\
\text { No } \\
\text { Yes } \\
\text { Total } \\
\end{array}$ & $\begin{array}{c}27(100.0) \\
0(0.0) \\
27(100.0) \\
\end{array}$ & $\begin{array}{c}56(100.0) \\
0(0.0) \\
56(100.0) \\
\end{array}$ & $\begin{array}{c}83(100.0) \\
0(0.0) \\
83(100.0) \\
\end{array}$ & \\
\hline $\begin{array}{l}\text { Forgetting } \\
\text { No } \\
\text { Yes } \\
\text { Total } \\
\end{array}$ & $\begin{array}{c}17(63.0) \\
10(37.0) \\
27(100.0) \\
\end{array}$ & $\begin{array}{c}41(73.2) \\
15(26.8) \\
56(100.0) \\
\end{array}$ & $\begin{array}{c}58(69.9) \\
25(30.1) \\
83(100.0) \\
\end{array}$ & 0.340 \\
\hline $\begin{array}{l}\text { Competing } \\
\text { priorities } \\
\text { No } \\
\text { Yes } \\
\text { Total } \\
\end{array}$ & $\begin{array}{c}10(37.0) \\
17(63.0) \\
27(100.0)\end{array}$ & $\begin{array}{c}25(44.6) \\
31(55.4) \\
56(100.0)\end{array}$ & $\begin{array}{l}35(42.2) \\
48(57.8) \\
83(100.0)\end{array}$ & 0.511 \\
\hline $\begin{array}{l}\text { Misinformation } \\
\text { No } \\
\text { Yes } \\
\text { Total } \\
\end{array}$ & $\begin{array}{c}18(66.7) \\
9(33.3) \\
27(100.0) \\
\end{array}$ & $\begin{array}{c}49(87.5) \\
7(12.5) \\
56(100.0) \\
\end{array}$ & $\begin{array}{c}67(80.7) \\
16(19.2) \\
83(100.0) \\
\end{array}$ & $0.024 *$ \\
\hline $\begin{array}{l}\text { Anxiety } \\
\text { No } \\
\text { Yes } \\
\text { Total }\end{array}$ & $\begin{array}{c}21(77.8) \\
6(22.2) \\
27(100.0)\end{array}$ & $\begin{array}{c}42(75.0) \\
14(25.0) \\
56(100.0)\end{array}$ & $\begin{array}{c}63(75.9) \\
20(24.1) \\
83(100.0)\end{array}$ & 0.782 \\
\hline $\begin{array}{l}\text { Motivation } \\
\text { No } \\
\text { Yes } \\
\text { Total } \\
\end{array}$ & $\begin{array}{c}15(55.6) \\
12(44.4) \\
27(100.0) \\
\end{array}$ & $\begin{array}{c}43(76.8) \\
13(23.2) \\
56(100.0) \\
\end{array}$ & $\begin{array}{c}58(69.9) \\
25(30.1) \\
83(100.0) \\
\end{array}$ & $0.048^{*}$ \\
\hline $\begin{array}{l}\text { Knowledge } \\
\text { No } \\
\text { Yes } \\
\text { Total } \\
\end{array}$ & $\begin{array}{c}14(51.9) \\
13(48.1) \\
27(100.0) \\
\end{array}$ & $\begin{array}{c}42(75.0) \\
14(25.0) \\
56(100.0) \\
\end{array}$ & $\begin{array}{c}56(67.5) \\
27(32.5) \\
83(100.0) \\
\end{array}$ & $0.035^{*}$ \\
\hline $\begin{array}{l}\text { Funds } \\
\text { No } \\
\text { Yes } \\
\text { Total } \\
\end{array}$ & $\begin{array}{c}9(33.3) \\
18(66.7) \\
27(100.0) \\
\end{array}$ & $\begin{array}{c}17(30.4) \\
39(69.6) \\
56(100.0) \\
\end{array}$ & $\begin{array}{c}26(31.3) \\
57(68.7) \\
83(100.0) \\
\end{array}$ & 0.784 \\
\hline $\begin{array}{l}\text { Facilities } \\
\text { No } \\
\text { Yes } \\
\text { Total } \\
\end{array}$ & $\begin{array}{c}11(40.7) \\
16(59.3) \\
27(100.0) \\
\end{array}$ & $\begin{array}{c}23(41.1) \\
33(58.9) \\
56(100.0) \\
\end{array}$ & $\begin{array}{c}34(41.0) \\
49(59.0) \\
83(100.0) \\
\end{array}$ & 0.977 \\
\hline $\begin{array}{l}\text { Attitude } \\
\text { No } \\
\text { Yes } \\
\text { Total }\end{array}$ & $\begin{array}{c}24(88.9) \\
3(11.1) \\
27(100.0)\end{array}$ & $\begin{array}{c}56(100.0) \\
0(0.0) \\
56(100.0)\end{array}$ & $\begin{array}{c}80(96.4) \\
3(3.6) \\
83(100.0)\end{array}$ & $0.011^{*}$ \\
\hline
\end{tabular}

Predictors of uptake of screening for diabetic retinopathy

Table 3 presents predictors of uptake of retinopathy screening. An adjusted regression analysis was conducted controlling for gender, attitude, misinformation and knowledge to determine significant predictors of screening rates for diabetic retinopathy in Zimbabwe. Gender $(\mathrm{OR}=0.241,95 \% \mathrm{CI}[0.079-0.735]$.$) and misinformation$ $(\mathrm{OR}=0.280,95 \%$ CI $[0.081-0.974]$.$) were significant$ predictors of uptake of screening. Knowledge was a promising factor $(\mathrm{OR}=0.333,95 \%$ CI [0.106- 1.048$]$.).
TABLE 3: PREDICTORS OF SCREENING RATES FOR DIABETIC RETINOPATHY

\begin{tabular}{|c|c|c|c|c|}
\hline $\begin{array}{c}\text { Screening } \\
\text { rates and: }\end{array}$ & $\begin{array}{c}\text { Adjusted } \\
\text { Odds } \\
\text { ratio } \\
\text { (AOR) }\end{array}$ & $\begin{array}{c}\text { Standard } \\
\text { error }\end{array}$ & P value & $\begin{array}{c}95 \% \text { Confidence } \\
\text { Interval }\end{array}$ \\
\hline Gender & 0.241 & 0.137 & $0.012^{*}$ & $0.079-0.735$ \\
\hline Misinformation & 0.280 & 0.178 & $0.045^{*}$ & $0.081-0.974$ \\
\hline Motivation & 0.597 & 0.349 & 0.377 & $0.190-1.875$ \\
\hline Knowledge & 0.333 & 0.195 & 0.060 & $0.106-1.048$ \\
\hline
\end{tabular}

\section{DISCUSSION}

\section{A. Demographic characteristics}

This study was conducted on a sample of 83 participants whereas some studies have used bigger sample sizes ranging from 100 to tens of thousands.[9, 10]. However, findings from this study remain generalizable to the population under study because sample size was calculated using estimates derived from the same population [1]. Other studies have even used smaller samples [11].

Mean age of the participants was 39 years. Younger age[9, 12], together with longer diabetes duration, triglyceride and low density lipoprotein and glycosylated haemoglobin have been associated with diabetic retinopathy[13, 14]. Other risk factors are type 1 diabetes for over a decade[15], nephropathy[16], sedentary lifestyle[17], systemic arterial hypertension[18], obesity, pregnancy, cataract surgery, genetics and puberty[19]. This makes timely and regular screening for diabetic retinopathy very important in the management of diabetic patients. Majority (74\%) participants had type II diabetes which might explain why almost a third of the participants fell within the 45-65 years' age group. Type II diabetes generally has an adult onset. Majority (44\%) had been diagnosed with diabetes mellitus within 0-2 years. This poses a perfect opportunity to adopt a screening culture to prevent or delay diabetic retinopathy. Diabetic retinopathy is progressive in nature and the risk increases with advancing duration and age[15].

Males comprised almost two thirds $(57,8 \%)$ of the sample and male gender was significantly associated with uptake of screening (44,6\% vs $22.9 \%$, p> 0.029). A study conducted in England reported similar results[9] In this study this could be due to the ability of men to pay for screening services. Being married was also associated with higher uptake of diabetic retinopathy screening. This still underscores the importance of spousal support financially, socially and psychologically. Financial barriers though not significant predictors of uptake in this study, were cited by $68.7 \%$ participants. More than half $(50.6 \%)$ participants earned less than RTGS $\$ 500$. This poses a serious financial constraint on people with diabetes mellitus in a hyperinflationary environment like Zimbabwe. Lower uptake in females could be due to competing demands as women generally tend to have more responsibilities than their male counterparts in the African culture. Uptake of diabetic retinopathy screening has been reported to be low in populations of low socioeconomic status[9].

\section{B. Uptake of screening}

Diabetic retinopathy screening, though not a complete eye test[20], is a key element in diabetes care for early detection of diabetic retinopathy because the disease does not cause any noticeable symptoms in its early stages[21]. Results from this 
study showed an uptake of diabetic retinopathy screening of $53 \%$. This is below the acceptable $70 \%$ and the optimal $80 \%$ recommended by the National Screening Committee[9] Consistently low rates of uptake of screening have been reported in studies conducted in Africa and other developing countries $[4,14,22,23]$. with higher rates ranging from 70 $91.9 \%$ having been reported in developed countries $[9,10,21]$ with settings like England recording rates of uptake from $55 \%$ to $95 \%$ [24].

\section{Barriers to screening}

Some barriers to the uptake of diabetic retinopathy screening include guilt of poor diabetic control, poor access to location of screening and lack of interest taken by the practice in diabetes care[9]. The major barrier to the uptake of diabetic retinopathy screening reported in this study was lack of funds as reported by $68.7 \%$ participants. Lack of finances as the major barrier to diabetic retinopathy screening[25, 26]. Diabetic retinopathy screening is not a free health service in Zimbabwe. It costs United States Dollars $\$ 100$ at Parirenyatwa Group of Hospitals and majority patients cannot afford it especially with the prevailing inflation in the country. More than half (59\%) participants cited lack of nearby facilities for screening and this explains the $61.4 \%$ that cited transport problems. Transport and access to screening do determine uptake of diabetic retinopathy screening[24] Parirenyatwa Group of Hospitals is a referral hospital located more than $10 \mathrm{~km}$ away from major residential high density areas. In this study misinformation, lack of motivation, negative attitudes towards screening and lack of knowledge were associated with low uptake of screening. On logistic regression, gender $(\mathrm{OR}=0.241,95 \%$ CI $[0.079-$ $0.735])$ and misinformation $(\mathrm{OR}=0.280,95 \%$ CI $[0.081-$ 0.974]) were significant predictors of uptake of screening. Communication with screening services, contacting patients, integration of screening and other care, focus on newly diagnosed individuals and perception of non-attenders are very essential in promoting uptake of screening[24]. In Zimbabwe, diabetic patients have to wait for six months or more before they can have their retinal screening due to limited public health facilities[4]. Non-attendance to vision, having competing priorities, anxiety, disengagement with diabetes care, misinformation, forgetfulness to go for screening, lack of coordination and collaboration in care and discomfort from eye drops are barriers to diabetic retinopathy screening[10].

\section{CONCLUSION}

Uptake of diabetic retinopathy screening was low. Gender and misinformation were significant predictors of uptake of screening. Individualised and structured health education in people with diabetes mellitus in view of the self-care required and the risk of both micro and macrovascular complications. However, this study had its own limitations. This was a hospital based study and participants could have given socially desirable responses that did not reflect true practice. Self-reports for data collection could have overestimated uptake and introduced recall bias. It is recommended that the study be replicated on a larger scale to improve generalisability.

\section{REFERENCES}

[1] Mutowo, M., et al., Prevalence of diabetes in Zimbabwe: a systematic review with meta-analysis. International journal of public health, 2015. 60(1): p. 1-11.

[2] Maboreke, N.P., Prevalence of diabetic retinopathy at Parirenyatwa hospital. 2016.

[3] Machingura, P.I., et al., Prevalence and risk factors associated with retinopathy in diabetic patients at Parirenyatwa Hospital outpatients' clinic in Harare, Zimbabwe. Archives of Medical and Biomedical Research, 2017. 3(2): p. 104-111.

[4] Matimba, A., et al., Tele-ophthalmology: opportunities for improving diabetes eye care in resource-and specialist-limited sub-Saharan African countries. Journal of telemedicine and telecare, 2016. 22(5): p. 311-316.

[5] Lee, R., T.Y. Wong, and C. Sabanayagam, Epidemiology of diabetic retinopathy, diabetic macular edema and related vision loss. Eye and vision, 2015. 2(1): p. 17.

[6] Reichel, E. and D. Salz, Diabetic retinopathy screening, in Managing Diabetic Eye Disease in Clinical Practice. 2015, Springer. p. 25-38.

[7] Lake, A., Reducing risk of vision loss for young adults with type 2 diabetes, 2018, Deakin University.

[8] Graham-Rowe, E., et al., Barriers and enablers to diabetic retinopathy screening attendance: Protocol for a systematic review. Systematic reviews, 2016. 5(1): p. 134.

[9] Moreton, R., et al., Factors determining uptake of diabetic retinopathy screening in Oxfordshire. Diabetic Medicine, 2017. 34(7): p. 993-999.

[10] Kashim, R., P. Newton, and O. Ojo, Diabetic retinopathy screening: A systematic review on patients' non-attendance. International journal of environmental research and public health, 2018. 15(1): p. 157.

[11] Hipwell, A., et al., Attitudes, access and anguish: a qualitative interview study of staff and patients' experiences of diabetic retinopathy screening. BMJ open, 2014. 4(12): p. e005498.

[12] Scanlon, P.H., The english national screening programme for diabetic retinopathy 2003-2016. Acta diabetologica, 2017. 54(6): p. 515-525.

[13] Bressler, S.B., et al., Change in diabetic retinopathy through 2 years: secondary analysis of a randomized clinical trial comparing aflibercept, bevacizumab, and ranibizumab. JAMA ophthalmology, 2017. 135(6): p. 558-568.

[14] Ahmed, R.A., S.N. Khalil, and M.A. Al-Qahtani, Diabetic retinopathy and the associated risk factors in diabetes type 2 patients in Abha, Saudi Arabia. Journal of family \& community medicine, 2016. 23(1): p. 18.

[15] Nentwich, M.M. and M.W. Ulbig, Diabetic retinopathy-ocular complications of diabetes mellitus. World journal of diabetes, 2015. 6(3): p. 489.

[16] Lima, V.C., et al., Risk factors for diabetic retinopathy: a casecontrol study. International journal of retina and vitreous, 2016. 2(1): p. 21.

[17] Bhavsar, A. and R. Khardori, Diabetic retinopathy, 2019.

[18] Mendanha, D.B.d.A., et al., Risk factors and incidence of diabetic retinopathy. Revista Brasileira de Oftalmologia, 2016. 75(6): p. 443446.

[19] Ting, D.S.W., G.C.M. Cheung, and T.Y. Wong, Diabetic retinopathy: global prevalence, major risk factors, screening practices and public health challenges: a review. Clinical \& experimental ophthalmology, 2016. 44(4): p. 260-277.

[20] Blows, P., T. Peto, and K. Mbulawa, Empowering patients with diabetic retinopathy. Community eye health, 2015. 28(92): p. s14.

[21] Jacomelli, J. Diabetic eye screening annual data 1 April 2015 to 31 March 2016. 2017.

[22] Mwangi, N., et al., Predictors of uptake of eye examination in people living with diabetes mellitus in three counties of Kenya. Tropical medicine and health, 2017. 45(1): p. 41.

[23] Poore, S., et al., Planning and developing services for diabetic retinopathy in Sub-Saharan Africa. International journal of health policy and management, 2015. 4(1): p. 19.

[24] Lindenmeyer, A., et al., Influence of primary care practices on patients' uptake of diabetic retinopathy screening: a qualitative case study. Br J Gen Pract, 2014. 64(625): p. e484-e492.

[25] Flaxman, S.R., et al., Global causes of blindness and distance vision impairment 1990-2020: a systematic review and meta-analysis. The Lancet Global Health, 2017. 5(12): p. e1221-e1234.

[26] Al-Alawi, A., et al., Knowledge, attitude, and perception of barriers for eye care among diabetic persons registered at Employee Health Department of a Tertiary Eye Hospital of Central Saudi Arabia. Middle East African journal of ophthalmology, 2016. 23(1): p. 71. 